\title{
Effect of Nutrient Management on the Growth and Yield of Cabbage (Brassica oleracea var. capitata $\mathbf{L}$.) in Calcareous Soils of Bangladesh
}

\author{
M. N. A. Naher ${ }^{1}$, M. N. Alam ${ }^{1}$ and N. Jahan ${ }^{2}$ \\ ${ }^{1}$ Department of Crop Science and Technology, Rajshahi University, Rajshahi, Bangladesh; \\ ${ }^{2}$ Deparment of Horticulture, BSMRAU, Gazipur, Bangladesh \\ *Corresponding author and Email: noorakter@yahoo.com
}

Received: 17 February 2014

Accepted: 13 December 2014

\begin{abstract}
An investigation was carried out in the calcareous soil of Chapai Nawabganj belonging to the High Ganges River Floodplain during November 2008 to March 2009 to examine the effect of different macro and micronutrients (N, P, K, S, Zn, B and Mo at 150, 50, 100, 20, 3, 3 and $1 \mathrm{~kg} / \mathrm{ha}$, respectively) on the growth and yield of cabbage. Application of different nutrients exhibited significant influence on the growth and yield of cabbage. The highest plant spread $(70.76 \mathrm{~cm})$, height $(37.89 \mathrm{~cm})$, leaf length $(37.83$ $\mathrm{cm})$, leaf breadth $(27.13 \mathrm{~cm})$, head thickness $(12.85 \mathrm{~cm})$, head diameter $(23.02 \mathrm{~cm})$, marketable head yield (76.53 t/ha) which is $191 \%$ increase over control), early head formation and maturity were recorded from the plot receiving $\mathrm{N}, \mathrm{P}, \mathrm{K}$ and $\mathrm{B}$ at the rate of $150,50,100$ and $3 \mathrm{~kg} / \mathrm{ha}$, respectively. The treatment N, P, K and S showed the highest weight of loose leaves $(640 \mathrm{~g} / \mathrm{plant})$ and decreased the weight of folded leaves or head weight, whereas, the treatment $\mathrm{N}, \mathrm{P}, \mathrm{K}$ and $\mathrm{B}$ increased the folded leaves or maximum head weight (1894.18 g/plant).
\end{abstract}

Keywords: Cabbage, fertilizer management, growth, yield

\section{Introduction}

Cabbage (Brassica oleracea var. capitata L.) is one of the most important, high nutritive and palatable leafy vegetables widely cultivated in Bangladesh. It is a rich source of protein, minerals and vitamin A (Uddin et al., 2009). It has some medicinal value as it prevents constipation, increases appetite, speeds up digestion and is very useful for diabetic patient. China is the leading cabbage producer (36,335,000 tons) all over the world (FAO, 2009). Bangladesh produces 211,097 tons from 16,102 hectares of land (BBS, 2009).

Fertilizer enhances plant growth by providing amendments to the soil via various macro and micronutrients. The fertilizer application for cabbage should ensure adequate levels of all nutrients. Optimum fertilization is required to produce top quality and high yields while a lack of essential fertilizers will stunt its growth, leading to undersized and poorly developed heads.

Cabbage is well known to be an exhaustive crop and has the capacity to absorb higher amount of nutrient from soil. The supply of proper nutrient must be ensured during its cultivation, which is related to the judicious application of fertilizer. In the upland field, cabbage yields were high when chemical fertilizers were applied (Kamiyama et al., 1995). The crop production system with high yield targets cannot be 
sustainable unless nutrient inputs to soil are at least balanced against nutrient removal by crops (Jahiruddin and Rijpma, 2004). Farmers of Bangladesh use only about $172 \mathrm{~kg}$ nutrients/ha annually (132 kg N, $17 \mathrm{~kg} \mathrm{P}, 17 \mathrm{~kg} \mathrm{~K}, 4 \mathrm{~kg} \mathrm{~S}$ and $2 \mathrm{~kg} \mathrm{Zn}+\mathrm{B}+$ others), while the crop removal is about $250 \mathrm{~kg} / \mathrm{ha}$ (Islam, 2002). As a result other nutrients such as $\mathrm{Mo}, \mathrm{Mn}, \mathrm{Mg}$ etc. are being observed as deficient in many parts of Bangladesh.

Some researchers investigated the effect of macro and micronutrients for cabbage production and recommended organic manure with macro and micronutrients to be added to the soil for increased head yield of cabbage (Farid $e t$ al., 1998). Boron is a very sensitive micronutrient and the range of deficiency and toxicity are narrow. However, in cole crops like cabbage, boron requirement is very high (Tisdale et al., 1995). Ullah et al. (1999) reported the significant influence of combined application of $\mathrm{N}, \mathrm{P}, \mathrm{K}$ and $\mathrm{S}$ on the yield of cabbage.

The average yield of cabbage is very low in Bangladesh compared to other developed countries due to unbalanced application of fertilizers and no consideration of micronutrients (Islam et al., 1989). Therefore, it is necessary to improve the yield of cabbage through judicious application of fertilizers. The present experiment was, therefore, conducted with the aim of improving the performance of cabbage in terms of yield and quality through the use of both macro and micronutrients in calcareous soil of Bangladesh.

\section{Materials and Methods}

\subsection{Experimental site and soil}

The investigation was carried out at the Horticulture Centre, Kallyanpur, Chapai Nawabganj during November 2008 to March 2009. The soil of the experimental site was silty clay loam belonging to the High Ganges River Floodplain (BARC, 2005). The organic matter and total nitrogen contents of the experimental field were very low while others nutrients were above critical level (Table 1).

\subsection{Experimental design and treatments}

The experiment was laid out in a Randomized Complete Block Design (RCBD) with three replications. Each block consisted of 11 unit plots. The size of each unit plot was $3.3 \mathrm{~m} \times 2.25$ $\mathrm{m}$. The gap between the plots was $50 \mathrm{~cm}$ and between the blocks was $100 \mathrm{~cm}$. A total of 11 treatments including the untreated control were selected in this investigation which were: $T_{0}=$ Control, $\mathrm{T}_{1}=\mathrm{N}, \mathrm{T}_{2}=\mathrm{NP}, \mathrm{T}_{3}=\mathrm{NPK}, \mathrm{T}_{4}=\mathrm{NPKS}$, $\mathrm{T}_{5}=\mathrm{NPKZn}, \mathrm{T}_{6}=\mathrm{NPKB}, \mathrm{T}_{7}=\mathrm{NPKMo}, \mathrm{T}_{8}=$ NPKSZn, $\quad \mathrm{T}_{9}=$ NPKSZnB and $\mathrm{T}_{10}=$ NPKSZnBMo. The doses of N, P, K, S, Zn, B and Mo were 150, 50,100, 20, 3, 3 and $1 \mathrm{~kg} / \mathrm{ha}$, respectively.

The sources of N, P, K, Zn, B, S and Mo were urea, triple super phosphate, muriate of potash, zinc oxide, boric acid, gypsum and ammonium molybdate, respectively. The whole amount of TSP, zinc oxide, boric acid, ammonium molybdate, and $50 \%$ of urea and MoP were applied during final land preparation. Rest MoP and urea were applied in two equal installments at 15 and 35 days after planting of seedlings followed by irrigation.

Table 1. Characteristics of the soils of experimental field

\begin{tabular}{llll}
\hline $\mathrm{pH}$ & 7.2 & Exchangeable K & $0.41 \mathrm{meq} / 100 \mathrm{~g}$ \\
Organic matter & $0.62 \%$ & Available S & $11.8 \mu \mathrm{g} / \mathrm{g}$ \\
Total N & $0.04(\%)$ & Available B & $0.48 \mu \mathrm{g} / \mathrm{g}$ \\
Available P & $29.0 \mu \mathrm{g} / \mathrm{g}$ & Available Zn & $1.32 \mu \mathrm{g} / \mathrm{g}$ \\
\hline
\end{tabular}




\subsection{Land preparation, transplantation of seedlings and intercultural operations}

The experimental land was prepared in first week of November 2008 by ploughing and cross ploughing followed by laddering. Large clods were broken into pieces by hand tools, and weeds and stubbles were removed from the field. Finally, the land was leveled and the soil was taken into good tilth. The cabbage seedling of cv. Atlas-70 was collected from the Horticulture Centre, Kallyanpur, Chapai Nawabganj. Thirty days old seedlings were transplanted into the experimental field on 15 November 2008, with a space of $55 \mathrm{~cm} \times 45 \mathrm{~cm}$. Thirty seedlings were planted in each plot and were lightly watered and kept under pieces of banana leaf sheath for 3 days during the day time to protect from sunlight.

Weeds were removed three times to keep the plots free from weeds and the soil was mulched by breaking the upper crust for easy aeration and to conserve soil moisture as and when needed. The crop was irrigated at 15, 35 and 55 days after transplantation. However, each topdressing was followed by irrigation. Any gap due to seedling mortality was filled by new seedlings. Malathion 57 EC @ 2 ml/L was sprayed once to control the cutworm.

\subsection{Harvest of crops and data collection}

Cabbage was harvested plot wise at different dates after attaining maturity. The crop was harvested from 11 February to 02 March 2009. Before harvesting, head compactness of the cabbage was tested by pressing with thumb. The compact or matured head showed comparatively hard feelings. Ten sample plants were harvested at first from each plot and then the whole plot was harvested. The yield of individual plot was converted into yield per hectare.

Data were collected from randomly selected 10 plants at 30, 45, 60, 75 days and at harvest. To avoid the border effect outer two lines and the outer plants of the middle lines were excluded. The height of the plants was measured from the ground level to the tip of the highest leaves.
Land area covered by the plant was estimated by putting a meter scale on the canopy and was expressed in centimeter. Length and breadth of the largest leaf was measured from the base of the petiole to the tip. To record the diameter, the cabbage heads were sectioned vertically at the middle position and the horizontal distance from one side to other side of the widest part of the sectioned head was measured. The thickness of head was measured as the vertical distance from the lower to the upper most leaves of head. Days required for head formation or maturity was counted from the date of transplanting to the start of head formation or maturity. In order to measure dry matter content in leaves or heads $200 \mathrm{~g}$ chopped leaves/head was dried in the direct sun for two days and then in an oven at $70^{\circ} \mathrm{C}$ for three days till the weight was constant. Percent dry matter was calculated by using the following formula:

Dry matter (\%)

$=\frac{\text { Dry weight of loose leaves } / \text { heads }}{\text { Fresh weight of loose leaves } / \text { heads }} \times 100$

The data were analyzed statistically using MSTAT-C, a statistical package programme. The analyses of variances of all the characters studied were performed by F-test. The significance of the differences among the means was evaluated by Duncan's Multiple Range Test (Gomez and Gomez, 1984).

\section{Results and Discussion}

\subsection{Plant spread}

There was significant influence of fertilizer treatments on the spread of cabbage plants at different growth period (Table 2). The spread was rapidly increased up to 60 days, and then gradually up to 75 days while after 75 days, the spread was gradually decreased.

At the initial stage of 30 or 45 days, the highest spread was recorded in treatment $\mathrm{T}_{6}$ which received $\mathrm{N}, \mathrm{P}, \mathrm{K}$ and $\mathrm{B}$. It seems that application of $\mathrm{N}, \mathrm{P}, \mathrm{K}$ and $\mathrm{B}$ significantly increased plant spread while $S$ and $Z n$ had negative effect. The results showed that the addition of $\mathrm{B}$ was more 
effective as B can be fixed with organic matter at primary stage. The results are in agreement with that reported by Das (1999) who reported that added $\mathrm{Ca}$ and $\mathrm{Mg}$ can fix available $\mathrm{B}$. Application of N P, K, S and Zn significantly increased plant spread. Similar response was noted after 60 and 75 days when the highest spread was obtained in $\mathrm{T}_{6}$. With a few exceptions, $S$ and $\mathrm{Zn}$ decreased the plant spread as they decrease B availability in the soil and B can fix with organic matter during early stage of crop growth. The results are in agreement with the observation of Tandon (1995) and Das (1999). A reduction in plant spread was recorded at the time of harvest although the highest coverage was noted in $\mathrm{T}_{6}$. The results of the present study is in agreement with that of Sarma et al. (2002), who reported reduced plant spread during harvest of cabbage and with the rate of spreading being slower compared to the increasing rate of previous growth period.

\subsection{Plant height}

The height of cabbage plant was significantly influenced by different fertilizer management (Table. 3). At the early stages of 30 and 45 days, the tallest plant was recorded in the treatment $\mathrm{T}_{6}$ which contained N, P, K and B while the shortest was observed in control plots. Similar result was recorded after 60 and 75 days. Plant height was slightly reduced at harvest. The decreasing rate was slower as compared with the increasing rate of previous growth stages. The tallest plant was recorded in $\mathrm{T}_{6}$ as before which was followed by $\mathrm{T}_{3}, \mathrm{~T}_{10}$ and $\mathrm{T}_{7}$. The results indicated that boron had significant effect on plant height when added with $\mathrm{N}, \mathrm{P}$ and $\mathrm{K}$ while sulfur, zinc or molybdenum had no effect at this stage.

\subsection{Length of largest leaf}

The size of leaf is an important growth parameter of cabbage which was significantly influenced due to different fertilizer treatments (Table 4). The leaf length was rapidly increased up to 60 days, then slowly up to 75 days and finally it was decreased at harvest. At 30 DAT, the largest leaf was found when $\mathrm{B}$ was added to the soil along with $\mathrm{N}, \mathrm{P}$ and $\mathrm{K}$ while it was the lowest in control plots. The results indicated that $\mathrm{B}$ as boric acid is directly absorbed by plants at initial stage. Similar results were noted after 45 and 60 days. The results showed that application of NPK + B significantly increased leaf size but $\mathrm{S}$ and $\mathrm{Zn}$ with NPK decreased the leaf size. The results were almost similar as recorded after 75 days and at the time of harvest. The results obtained at harvest indicated that boron had prominent effect while $S$ and Mo had no effect on the length of cabbage leaf when added with NPK.

Table 2. The spread of cabbage plant as influenced by different fertilizer management

\begin{tabular}{lccccc}
\hline Treatments & \multicolumn{5}{c}{ Plant spread $(\mathrm{cm})$ at } \\
\cline { 2 - 6 } & 30 DAT & 45 DAT & 60 DAT & 75 DAT & Harvest \\
\hline $\mathrm{T}_{0}=$ Control & $28.73 \mathrm{~h}$ & $33.57 \mathrm{i}$ & $39.57 \mathrm{~h}$ & $43.34 \mathrm{~h}$ & $42.22 \mathrm{~h}$ \\
$\mathrm{~T}_{1}=\mathrm{N}$ & $31.47 \mathrm{~g}$ & $37.77 \mathrm{~h}$ & $45.60 \mathrm{~g}$ & $53.27 \mathrm{~g}$ & $52.02 \mathrm{~g}$ \\
$\mathrm{~T}_{2}=\mathrm{NP}$ & $34.10 \mathrm{f}$ & $43.30 \mathrm{~g}$ & $52.45 \mathrm{f}$ & $59.29 \mathrm{f}$ & $56.34 \mathrm{f}$ \\
$\mathrm{T}_{3}=\mathrm{NPK}$ & $39.60 \mathrm{~cd}$ & $48.53 \mathrm{de}$ & $58.30 \mathrm{~cd}$ & $63.66 \mathrm{de}$ & $61.93 \mathrm{de}$ \\
$\mathrm{T}_{4}=\mathrm{NPKS}$ & $36.44 \mathrm{e}$ & $45.00 \mathrm{f}$ & $55.93 \mathrm{e}$ & $62.73 \mathrm{e}$ & $61.40 \mathrm{e}$ \\
$\mathrm{T}_{5}=\mathrm{NPKZn}$ & $38.47 \mathrm{~d}$ & $47.63 \mathrm{e}$ & $57.40 \mathrm{de}$ & $64.26 \mathrm{~d}$ & $62.80 \mathrm{~d}$ \\
$\mathrm{~T}_{6}=\mathrm{NPKB}$ & $45.64 \mathrm{a}$ & $54.43 \mathrm{a}$ & $65.33 \mathrm{a}$ & $71.45 \mathrm{a}$ & $70.76 \mathrm{a}$ \\
$\mathrm{T}_{7}=\mathrm{NPKMo}$ & $41.10 \mathrm{e}$ & $50.70 \mathrm{bc}$ & $59.29 \mathrm{bc}$ & $67.33 \mathrm{c}$ & $65.30 \mathrm{c}$ \\
$\mathrm{T}_{8}=\mathrm{NPKSZn}$ & $38.53 \mathrm{~d}$ & $48.53 \mathrm{de}$ & $58.20 \mathrm{~cd}$ & $64.41 \mathrm{~d}$ & $62.75 \mathrm{e}$ \\
$\mathrm{T}_{9}=\mathrm{NPKSZnB}$ & $39.37 \mathrm{~cd}$ & $49.43 \mathrm{ed}$ & $58.37 \mathrm{~cd}$ & $68.37 \mathrm{c}$ & $67.50 \mathrm{~b}$ \\
$\mathrm{~T}_{10}=\mathrm{NPKSZnBMo}$ & $42.83 \mathrm{~b}$ & $51.24 \mathrm{~b}$ & $60.37 \mathrm{~b}$ & $69.86 \mathrm{~b}$ & $66.50 \mathrm{~b}$ \\
\hline LSD $(\mathrm{P} \geq 0.05)$ & 1.68 & 1.51 & 1.62 & 1.27 & 1.35 \\
$\mathrm{CV}(\%)$ & 2.61 & 1.9 & 1.72 & 1.19 & 1.52 \\
\hline
\end{tabular}


Table 3. Height of the cabbage plants as influenced by different fertilizer managements

\begin{tabular}{llllll}
\hline \multicolumn{1}{c}{ Treatments } & \multicolumn{5}{c}{ Plant height $(\mathrm{cm})$ at } \\
\cline { 2 - 6 } & $30 \mathrm{DAT}$ & $45 \mathrm{DAT}$ & $60 \mathrm{DAT}$ & $75 \mathrm{DAT}$ & Harvest \\
\hline $\mathrm{T}_{0=}$ Control & $23.53 \mathrm{~h}$ & $24.70 \mathrm{f}$ & $25.79 \mathrm{f}$ & $26.44 \mathrm{~g}$ & $26.31 \mathrm{~g}$ \\
$\mathrm{~T}_{1}=\mathrm{N}$ & $26.30 \mathrm{~g}$ & $29.77 \mathrm{e}$ & $31.07 \mathrm{e}$ & $32.00 \mathrm{f}$ & $31.45 \mathrm{f}$ \\
$\mathrm{T}_{2}=\mathrm{NP}$ & $28.10 \mathrm{ef}$ & $30.32 \mathrm{de}$ & $32.27 \mathrm{~d}$ & $34.02 \mathrm{e}$ & $33.76 \mathrm{~d}$ \\
$\mathrm{~T}_{3}=\mathrm{NPK}$ & $30.27 \mathrm{bcd}$ & $34.78 \mathrm{a}$ & $35.74 \mathrm{~b}$ & $36.83 \mathrm{~b}$ & $36.52 \mathrm{~b}$ \\
$\mathrm{~T}_{4}=\mathrm{NPKS}$ & $26.73 \mathrm{fg}$ & $30.81 \mathrm{cde}$ & $32.31 \mathrm{~d}$ & $33.40 \mathrm{e}$ & $32.96 \mathrm{de}$ \\
$\mathrm{T}_{5}=\mathrm{NPKZn}$ & $29.09 \mathrm{de}$ & $31.22 \mathrm{bcd}$ & $33.11 \mathrm{~cd}$ & $34.15 \mathrm{e}$ & $33.70 \mathrm{~d}$ \\
$\mathrm{~T}_{6}=\mathrm{NPKB}$ & $32.42 \mathrm{a}$ & $35.13 \mathrm{a}$ & $36.93 \mathrm{a}$ & $38.23 \mathrm{a}$ & $37.89 \mathrm{a}$ \\
$\mathrm{T}_{7}=\mathrm{NPKMo}$ & $31.37 \mathrm{ab}$ & $32.25 \mathrm{~b}$ & $33.80 \mathrm{c}$ & $35.33 \mathrm{~cd}$ & $35.01 \mathrm{c}$ \\
$\mathrm{T}_{8}=\mathrm{NPKSZn}$ & $28.96 \mathrm{de}$ & $30.70 \mathrm{cde}$ & $32.77 \mathrm{~d}$ & $33.82 \mathrm{e}$ & $33.33 \mathrm{de}$ \\
$\mathrm{T}_{9}=\mathrm{NPKSZnB}$ & $29.65 \mathrm{~cd}$ & $31.87 \mathrm{bc}$ & $32.49 \mathrm{~d}$ & $34.49 \mathrm{de}$ & $33.88 \mathrm{~cd}$ \\
$\mathrm{~T}_{10}=\mathrm{NPKSZnBMo}$ & $30.67 \mathrm{bc}$ & $32.19 \mathrm{~b}$ & $33.76 \mathrm{c}$ & $35.80 \mathrm{c}$ & $35.42 \mathrm{bc}$ \\
\hline LSD $(\mathrm{P} \geq 0.05)$ & 1.42 & 1.17 & 0.94 & 1.00 & 1.22 \\
CV $(\%)$ & 2.9 & 2.19 & 1.69 & 1.73 & 1.60 \\
\hline
\end{tabular}

In a column, figures having same letters do not differ significantly by DMRT at 5\% level.

Table 4. Length of largest leaf of cabbage at different growth period as influenced by different nutrient combinations

\begin{tabular}{llllll}
\hline Treatments & \multicolumn{5}{c}{ Largest leaf length $(\mathrm{cm})$ at } \\
\cline { 2 - 6 } & $30 \mathrm{DAT}$ & $45 \mathrm{DAT}$ & $60 \mathrm{DAT}$ & $75 \mathrm{DAT}$ & Harvest \\
\hline T0=Control & $17.83 \mathrm{f}$ & $22.71 \mathrm{~d}$ & $24.09 \mathrm{f}$ & $24.97 \mathrm{~h}$ & $24.45 \mathrm{~g}$ \\
T1=N & $20.15 \mathrm{e}$ & $28.11 \mathrm{c}$ & $29.13 \mathrm{e}$ & $30.43 \mathrm{~g}$ & $29.96 \mathrm{f}$ \\
T2=NP & $22.413 \mathrm{~d}$ & $28.96 \mathrm{c}$ & $31.59 \mathrm{~d}$ & $32.10 \mathrm{f}$ & $31.98 \mathrm{e}$ \\
T3=NPK & $24.83 \mathrm{bc}$ & $31.11 \mathrm{~b}$ & $33.83 \mathrm{bc}$ & $34.73 \mathrm{~cd}$ & $34.56 \mathrm{bc}$ \\
T4=NPKS & $24.43 \mathrm{c}$ & $30.75 \mathrm{~b}$ & $33.67 \mathrm{bc}$ & $33.93 \mathrm{e}$ & $33.43 \mathrm{~d}$ \\
T5=NPKZn & $24.95 \mathrm{bc}$ & $30.93 \mathrm{~b}$ & $34.73 \mathrm{~b}$ & $35.37 \mathrm{bc}$ & $35.07 \mathrm{~b}$ \\
T6=NPKB & $26.19 \mathrm{a}$ & $32.36 \mathrm{a}$ & $35.97 \mathrm{a}$ & $38.33 \mathrm{a}$ & $37.83 \mathrm{a}$ \\
T7=NPKMo & $24.27 \mathrm{c}$ & $30.96 \mathrm{~b}$ & $33.73 \mathrm{bc}$ & $34.10 \mathrm{de}$ & $33.72 \mathrm{~cd}$ \\
T8=NPKSZn & $24.00 \mathrm{c}$ & $30.57 \mathrm{~b}$ & $33.20 \mathrm{c}$ & $34.07 \mathrm{de}$ & $33.87 \mathrm{c}$ \\
T9=NPKSZnB & $24.20 \mathrm{c}$ & $31.12 \mathrm{~b}$ & $34.17 \mathrm{bc}$ & $35.17 \mathrm{bc}$ & $34.67 \mathrm{bc}$ \\
T10=NPKSZnBMo & $25.87 \mathrm{ab}$ & $31.65 \mathrm{ab}$ & $34.70 \mathrm{~b}$ & $35.63 \mathrm{~b}$ & $34.93 \mathrm{bc}$ \\
\hline LSD $(\mathrm{P} \geq 0.05)$ & 1.11 & 1.09 & 0.95 & 0.67 & 0.80 \\
CV $(\%)$ & 2.77 & 2.12 & 1.71 & 1.16 & 1.21 \\
\hline
\end{tabular}

In a column, figures having same letters do not differ significantly by DMRT at 5\% level.

\subsection{Breadth of the largest leaf}

The breadth of leaves of cabbage is an important parameter for proper head formation. Different nutrient management had significant effect on the breadth of leaves (Table 5). The breadth was increased gradually up to 45 days, then rapidly and finally slowly from 75 days. The widest leaf was recorded in treatment $T_{6}$ having $\mathrm{N}, \mathrm{P}, \mathrm{K}$ and $\mathrm{B}$ at all growth periods. The effect of $\mathrm{B}$ was most prominent when added any other nutrients. The results revealed that $B$ in addition to NPK showed positive response on leaf breath at all 
growth periods. The lowest breadth of largest leaf always recorded in unfertilized control plots. The results showed that molybdenum did not show any significant effect on leaf breadth. Sulfur exhibited negative response on leaf breadth of cabbage at all growth stage. When Zn was added with NPK, it did not exhibit any effect, while the combination of $\mathrm{S}$ and $\mathrm{Zn}$ with NPK increased leaf breadth significantly.

\subsection{Days required for head formation}

Application of different nutrients and their combinations exhibited significant influence on head formation (Table 6). The control plots required the longest time (59.16 days) for head formation, while NPKB required only 43.89 days although it was statistically similar to NPKZn, NPKSZn and NPKSZnBMo. NPKS delayed head formation. It required 49.46 days. Application of NPK took only 47.50 days for head formation. Alam (2007) reported that early head formation of cabbage was significantly influenced by the application of B fertilizer in calcareous soils of Bangladesh. This indicates that head formation of cabbage is sensitive to B, but has inverse relation with $\mathrm{S}$.

\subsection{Days required for head maturity}

Different fertilizer combinations had significant effect on days required for head maturity of cabbage (Table 6). The cabbage grown in the plot receiving $\mathrm{N}, \mathrm{P}$ and $\mathrm{K}$ with $\mathrm{B}\left(\mathrm{T}_{6}\right)$ required minimum days (88.92 days) for maturity although it was statistically similar with the treatments $\mathrm{T}_{5}, \mathrm{~T}_{7}, \mathrm{~T}_{8}, \mathrm{~T}_{9}$ and $\mathrm{T}_{10}$. Maturity of head was delayed by one day due to $S$ application when added to NPK fertilizers as compared with only NPK treatments. The results showed that B inhibits early maturity whereas $\mathrm{S}$ delayed it in calcareous soils. The results are in partial agreement with the findings of WangXiude et al. (1996).

\subsection{Weight of root}

Root weight of cabbage plants was significantly influenced by different fertilizer treatments (Table 6). The maximum weight (35.61 g/plant) was recorded in treatment $\mathrm{T}_{3}$ (receiving $\mathrm{N}, \mathrm{P}$ and
$\mathrm{K}$ only) while the minimum was recorded in unfertilized control plots $(20.66 \mathrm{~g})$. The results showed that application of $\mathrm{N}, \mathrm{P}$ and $\mathrm{K}$ increased the weight of root whereas application of $\mathrm{B}, \mathrm{Zn}$ and Mo had no such effect.

\subsection{Weight of stem}

The maximum weight $(33.66 \mathrm{~g} / \mathrm{plant})$ of stem was found in treatment $\mathrm{T}_{3}$ (receiving $\mathrm{N}, \mathrm{P}$ and $\mathrm{K}$ only) while the minimum (22.48 g) was obtained from unfertilized control plots. The results showed that application of $\mathrm{N}, \mathrm{P}$ and $\mathrm{K}$ increased the weight of stem whereas application of $\mathrm{B}, \mathrm{Zn}$ and Mo had no such effect.

\subsection{Weight of loose leaves}

The maximum weight of loose leaves (640 $\mathrm{g} /$ plant) was obtained from $\mathrm{T}_{4}$ (NPKS), whereas the lowest value was recorded in control plots. This result indicated that folding mechanism is directly related with nutrients. When B was added with NPK, the weight of loose leaves was decreased but started early head formation and maturity. Application of $\mathrm{S}$ with NPK significantly increased the weight of loose leaves but delayed head formation and head maturity. The results are in full agreement with that of Haro and Sonoda (1981).

\subsection{Dry matter of loose leaves}

There was no significant effect of nutrients on the dry matter accumulation in loose leaves of cabbage (Table 6) although the highest dry matter $(9.34 \%)$ was found in $\mathrm{T}_{4}$ while the lowest $(8.36 \%)$ was in treatment $\mathrm{T}_{3}$.

\subsection{Dry matter of head}

The highest dry matter content $(6.62 \%)$ of cabbage head was recorded in treatment $T_{8}$ (receiving $\mathrm{N}, \mathrm{P}, \mathrm{K}, \mathrm{S}$ and $\mathrm{Zn}$ ), whereas the lowest was in $\mathrm{T}_{1}$ (receiving $\mathrm{N}$ only). The results indicated that application of $\mathrm{K}, \mathrm{S}$ and $\mathrm{Mo}$ decreased dry matter whereas $\mathrm{P}, \mathrm{Zn} \& \mathrm{~B}$ increased head dry matter content of cabbage.

\subsection{Diameter of cabbage head}

The diameter of cabbage head at harvest 
responded significantly to fertilizer application and varied from 11.18 to $23.02 \mathrm{~cm}$ (Table 7). The maximum diameter of the head was recorded in the plot where $\mathrm{B}$ was added with
NPK while the smallest $(11.18 \mathrm{~cm})$ was noted in control plots. The results showed that NPKB significantly increased the head diameter while $\mathrm{Zn}$ and $\mathrm{S}$ decreased it.

Table 5. Breadth of the largest leaf of cabbage as influenced by different nutrient management at five growth stages

\begin{tabular}{llllll}
\hline \multirow{2}{*}{ Treatments } & \multicolumn{5}{c}{ Breadth of the largest leaf $(\mathrm{cm})$} \\
\cline { 2 - 6 } & 30 DAT & 45 DAT & 60 DAT & 75 DAT & Harvest \\
\hline $\mathrm{T}_{0=}$ Control & $10.90 \mathrm{~d}$ & $12.01 \mathrm{~g}$ & $16.18 \mathrm{e}$ & $16.58 \mathrm{~g}$ & $15.58 \mathrm{~g}$ \\
$\mathrm{~T}_{1}=\mathrm{N}$ & $11.75 \mathrm{~cd}$ & $14.53 \mathrm{f}$ & $20.86 \mathrm{~d}$ & $23.03 \mathrm{f}$ & $21.93 \mathrm{f}$ \\
$\mathrm{T}_{2}=\mathrm{NP}$ & $12.59 \mathrm{bcd}$ & $15.25 \mathrm{f}$ & $21.31 \mathrm{~d}$ & $24.67 \mathrm{e}$ & $23.37 \mathrm{e}$ \\
$\mathrm{T}_{3}=\mathrm{NPK}$ & $15.50 \mathrm{abc}$ & $18.19 \mathrm{~d}$ & $23.53 \mathrm{c}$ & $26.87 \mathrm{bc}$ & $25.84 \mathrm{bc}$ \\
$\mathrm{T}_{4}=\mathrm{NPKS}$ & $13.63 \mathrm{abcd}$ & $16.67 \mathrm{e}$ & $21.48 \mathrm{~d}$ & $25.41 \mathrm{de}$ & $23.91 \mathrm{de}$ \\
$\mathrm{T}_{5}=\mathrm{NPKZn}$ & $15.93 \mathrm{ab}$ & $20.33 \mathrm{bc}$ & $23.90 \mathrm{bc}$ & $26.23 \mathrm{~cd}$ & $25.23 \mathrm{c}$ \\
$\mathrm{T}_{6}=\mathrm{NPKB}$ & $17.28 \mathrm{a}$ & $22.26 \mathrm{a}$ & $25.93 \mathrm{a}$ & $28.43 \mathrm{a}$ & $27.13 \mathrm{a}$ \\
$\mathrm{T}_{7}=\mathrm{NPKMo}$ & $14.78 \mathrm{abc}$ & $19.87 \mathrm{c}$ & $23.54 \mathrm{e}$ & $25.88 \mathrm{~cd}$ & $24.48 \mathrm{~d}$ \\
$\mathrm{~T}_{8}=\mathrm{NPKSZn}$ & $15.38 \mathrm{abc}$ & $21.13 \mathrm{ab}$ & $24.20 \mathrm{bc}$ & $26.87 \mathrm{bc}$ & $25.87 \mathrm{bc}$ \\
$\mathrm{T}_{9}=\mathrm{NPKSZnB}$ & $16.04 \mathrm{ab}$ & $21.63 \mathrm{a}$ & $24.68 \mathrm{~b}$ & $27.34 \mathrm{~b}$ & $26.34 \mathrm{~b}$ \\
$\mathrm{~T}_{10}=\mathrm{NPKSZnBMo}$ & $16.24 \mathrm{ab}$ & $21.73 \mathrm{a}$ & $24.68 \mathrm{~b}$ & $26.64 \mathrm{c}$ & $26.38 \mathrm{~b}$ \\
\hline LSD $(\mathrm{P} \geq 0.05)$ & 3.37 & 1.15 & 1.02 & 1.02 & 1.12 \\
$\mathrm{CV}(\%)$ & 13.67 & 3.34 & 2.62 & 2.36 & 2.24 \\
\hline
\end{tabular}

In a column, figures having same letters do not differ significantly by DMRT at 5\% level.

Table 6. Effect of nutrient management on growth and yield parameters of cabbage

\begin{tabular}{lccccccc}
\hline \multicolumn{1}{c}{ Treatments } & $\begin{array}{c}\text { Days } \\
\text { required } \\
\text { to head } \\
\text { formation }\end{array}$ & $\begin{array}{c}\text { Days } \\
\text { required } \\
\text { for head } \\
\text { maturity }\end{array}$ & $\begin{array}{c}\text { Wt. of } \\
\text { root } \\
(\mathrm{g} / \mathrm{plant})\end{array}$ & $\begin{array}{c}\text { Wt. of } \\
\text { stem } \\
(\mathrm{g} / \mathrm{plant})\end{array}$ & $\begin{array}{c}\text { Wt. of } \\
\text { loose } \\
\text { leaves } \\
(\mathrm{g} / \mathrm{plant})\end{array}$ & $\begin{array}{c}\text { DM of } \\
\text { loose } \\
\text { leaves } \\
(\%)\end{array}$ & $\begin{array}{c}\text { Dry matter } \\
\text { of } \\
\text { head } \\
(\%)\end{array}$ \\
\hline $\mathrm{T}_{0=\text { Control }}$ & $59.16 \mathrm{a}$ & $106.19 \mathrm{a}$ & $20.66 \mathrm{~g}$ & $22.48 \mathrm{~d}$ & $360 \mathrm{f}$ & $9.20 \mathrm{a}$ & $5.36 \mathrm{~d}$ \\
$\mathrm{~T}_{1}=\mathrm{N}$ & $53.34 \mathrm{~b}$ & $93.78 \mathrm{~b}$ & $26.30 \mathrm{f}$ & $31.52 \mathrm{bc}$ & $410 \mathrm{e}$ & $8.71 \mathrm{a}$ & $5.35 \mathrm{~d}$ \\
$\mathrm{~T}_{2}=\mathrm{NP}$ & $50.80 \mathrm{c}$ & $92.17 \mathrm{~cd}$ & $30.52 \mathrm{e}$ & $33.11 \mathrm{ab}$ & $520 \mathrm{c}$ & $9.31 \mathrm{a}$ & $6.36 \mathrm{ab}$ \\
$\mathrm{T}_{3}=\mathrm{NPK}$ & $47.50 \mathrm{~d}$ & $92.21 \mathrm{~cd}$ & $35.61 \mathrm{a}$ & $33.66 \mathrm{a}$ & $570 \mathrm{~b}$ & $8.36 \mathrm{a}$ & $5.62 \mathrm{~cd}$ \\
$\mathrm{~T}_{4}=\mathrm{NPKS}$ & $49.46 \mathrm{c}$ & $93.33 \mathrm{bc}$ & $31.89 \mathrm{cde}$ & $32.55 \mathrm{abc}$ & $640 \mathrm{a}$ & $9.34 \mathrm{a}$ & $5.42 \mathrm{~d}$ \\
$\mathrm{~T}_{5}=\mathrm{NPKZn}$ & $45.50 \mathrm{ef}$ & $91.20 \mathrm{de}$ & $32.88 \mathrm{bc}$ & $31.91 \mathrm{bc}$ & $506 \mathrm{e}$ & $8.94 \mathrm{a}$ & $6.53 \mathrm{a}$ \\
$\mathrm{T}_{6}=\mathrm{NPKB}$ & $43.89 \mathrm{f}$ & $88.92 \mathrm{e}$ & $32.21 \mathrm{bcd}$ & $31.25 \mathrm{c}$ & $511 \mathrm{c}$ & $9.13 \mathrm{a}$ & $6.24 \mathrm{abc}$ \\
$\mathrm{T}_{7}=\mathrm{NPKMo}$ & $46.62 \mathrm{de}$ & $91.11 \mathrm{de}$ & $33.30 \mathrm{bc}$ & $31.31 \mathrm{c}$ & $423 \mathrm{e}$ & $8.54 \mathrm{a}$ & $5.58 \mathrm{~cd}$ \\
$\mathrm{~T}_{8}=\mathrm{NPKSZn}$ & $45.56 \mathrm{ef}$ & $90.75 \mathrm{e}$ & $33.47 \mathrm{~b}$ & $32.12 \mathrm{abc}$ & $470 \mathrm{~d}$ & $8.93 \mathrm{a}$ & $6.62 \mathrm{a}$ \\
$\mathrm{T}_{9}=\mathrm{NPKSZnB}$ & $44.89 \mathrm{f}$ & $90.17 \mathrm{e}$ & $33.52 \mathrm{~b}$ & $32.49 \mathrm{abc}$ & $460 \mathrm{~d}$ & $9.07 \mathrm{a}$ & $6.33 \mathrm{ab}$ \\
$\mathrm{T}_{10}=\mathrm{NPKSZnBMo}$ & $44.89 \mathrm{f}$ & $90.17 \mathrm{e}$ & $33.52 \mathrm{~b}$ & $32.49 \mathrm{abc}$ & $460 \mathrm{~d}$ & $9.07 \mathrm{a}$ & $6.33 \mathrm{ab}$ \\
\hline $\mathrm{LSD}(\mathrm{P} \geq 0.05)$ & 1.55 & 1.14 & 1.32 & 1.43 & 17.49 & 1.37 & 0.65 \\
$\mathrm{CV}(\%)$ & 1.87 & 0.72 & 2.49 & 2.67 & 2.12 & 2.84 & 6.44 \\
\hline
\end{tabular}

In a column, figures having same letters do not differ significantly by DMRT at $5 \%$ level. 
Table 7. Yield and yield components of cabbage as influenced by nutrient management.

\begin{tabular}{lccccc}
\hline Treatments & $\begin{array}{c}\text { Head diameter } \\
(\mathrm{cm})\end{array}$ & $\begin{array}{c}\text { Head } \\
\text { thickness } \\
(\mathrm{cm})\end{array}$ & $\begin{array}{c}\text { Weight of } \\
\text { marketable } \\
\text { head }(\mathrm{g})\end{array}$ & Yield (t/ha) & $\begin{array}{l}\text { Increased } \\
\text { yield }(\%) \\
\text { over control }\end{array}$ \\
\hline $\mathrm{T}_{0}=$ Control & $11.18 \mathrm{~g}$ & $8.25 \mathrm{f}$ & $650.16 \mathrm{~h}$ & $26.27 \mathrm{~h}$ & - \\
$\mathrm{T}_{1}=\mathrm{N}$ & $15.02 \mathrm{f}$ & $9.27 \mathrm{e}$ & $1078.04 \mathrm{~g}$ & $43.56 \mathrm{~g}$ & 66 \\
$\mathrm{~T}_{2}=\mathrm{NP}$ & $17.51 \mathrm{e}$ & $10.42 \mathrm{~d}$ & $1201.99 \mathrm{f}$ & $48.56 \mathrm{f}$ & 85 \\
$\mathrm{~T}_{3}=\mathrm{NPK}$ & $19.72 \mathrm{~d}$ & $10.77 \mathrm{~cd}$ & $1298.05 \mathrm{e}$ & $53.55 \mathrm{e}$ & 104 \\
$\mathrm{~T}_{4}=\mathrm{NPKS}$ & $20.17 \mathrm{~cd}$ & $11.37 \mathrm{bcd}$ & $1418.80 \mathrm{~d}$ & $52.45 \mathrm{~d}$ & 100 \\
$\mathrm{~T}_{5}=\mathrm{NPKZn}$ & $22.50 \mathrm{ab}$ & $12.00 \mathrm{ab}$ & $1779.51 \mathrm{~b}$ & $57.32 \mathrm{~b}$ & 118 \\
$\mathrm{~T}_{6}=\mathrm{NPKB}$ & $23.02 \mathrm{a}$ & $12.85 \mathrm{a}$ & $1894.18 \mathrm{a}$ & $76.53 \mathrm{a}$ & 191 \\
$\mathrm{~T}_{7}=\mathrm{NPKMo}$ & $20.57 \mathrm{bcd}$ & $11.88 \mathrm{ab}$ & $1661.46 \mathrm{e}$ & $71.90 \mathrm{c}$ & 174 \\
$\mathrm{~T}_{8}=\mathrm{NPKSZn}$ & $20.97 \mathrm{bc}$ & $12.16 \mathrm{ab}$ & $1785.73 \mathrm{~b}$ & $67.13 \mathrm{~d}$ & 156 \\
$\mathrm{~T}_{9}=\mathrm{NPKSZnB}$ & $21.50 \mathrm{~b}$ & $12.48 \mathrm{ab}$ & $1827.06 \mathrm{ab}$ & $72.15 \mathrm{ab}$ & 175 \\
$\mathrm{~T}_{10}=\mathrm{NPKSZnBMo}$ & $21.50 \mathrm{~b}$ & $12.48 \mathrm{ab}$ & $1827.06 \mathrm{ab}$ & $73.82 \mathrm{ab}$ & 181 \\
\hline $\mathrm{LSD}(\mathrm{P} \geq 0.05)$ & 0.91 & 1.02 & 90.86 & 1.09 & \\
$\mathrm{CV}(\%)$ & 2.75 & 5.34 & 3.69 & 3.69 & \\
\hline
\end{tabular}

In a column, figures having same letters do not differ significantly by DMRT at 5\% level.

\subsection{Head thickness}

The thickness of cabbage head from 8.25 to $12.85 \mathrm{~cm}$ and was significantly influenced by nutrient management (Table 7). The maximum head thickness of $12.85 \mathrm{~cm}$ was recorded in treatment $\mathrm{T}_{6}$ (receiving $\mathrm{N}, \mathrm{P}, \mathrm{K}$ and $\mathrm{B}$ ) although it was statistically identical with $\mathrm{T}_{5}, \mathrm{~T}_{7}, \mathrm{~T}_{8}, \mathrm{~T}_{9}$ and $\mathrm{T}_{10}$. It was observed that $\mathrm{B}$ had positive effect on cabbage thickness when added with $\mathrm{N}$, $\mathrm{P}$ and $\mathrm{K}$ while other micronutrients were not able to exhibit such effect.

\subsection{Marketable head}

The marketable head of cabbage responded significantly due to nutrient management and it ranged from 650.16 to $1894.18 \mathrm{~g} /$ plant (Table 7). The highest weight of marketable heads of $1894.18 \mathrm{~g} /$ plant was obtained from the treatment $\mathrm{T}_{6}(\mathrm{~N}, \mathrm{P}, \mathrm{K}$ and $\mathrm{B}$ ) while the lightest heads were recorded in the control plots.

\subsection{Yield}

Different fertilizer managements created a significant impact on the yield of cabbage (Table $7)$. Wide variation was noted in cabbage yield (26.27 to $76.53 \mathrm{t} / \mathrm{ha}$ ). The head yield directly depends on head weight of cabbage. The highest yield (76.53 t/ha) as well as $191 \%$ increase over control was obtained from the treatment $\mathrm{T}_{6}$ which contained $\mathrm{N}, \mathrm{P}, \mathrm{K}$ and $\mathrm{B}$. There were no significant differences in yields among the treatments $\mathrm{T}_{6}, \mathrm{~T}_{9}$ and $\mathrm{T}_{10}$. The lowest yield was recorded in the control plots.

The results revealed that all the fertilizers contributed on the yield of cabbage while the effect of $\mathrm{B}$ was more prominent than other nutrients. Sulfur exhibited reduced yield when added with NPK as compared with the yield under NPK. It seems that $\mathrm{S}$ had negative effect on the yield. It was observed that $\mathrm{N}$ alone could increase yields by $66 \%$, while NP, NPK, NPKS, NPKZn, NPKB, NPKM, NPKSZn, NPKSZnB, and NPKSZnBMo increase yields by 85,104 , $100,118,191$, o 174, 156, $175181 \%$, respectively over control. These results agree with the observation of Alam (2007) who obtained the highest yield of cabbage by applying boron as boric acid at $4 \mathrm{~kg} / \mathrm{ha}$ although it was similar to that given by $3 \mathrm{~kg} / \mathrm{ha}$. Sarma et al. (2002) recorded the highest yield of cabbage (cv. Green express) with the application of $0.5 \%$ borax. Similarly, Kanujia et al. (2006) recorded the maximum yield of cabbage (var. Golden 
Acre) with foliar application of mixture of boron and other micronutrients at the rate of $100 \mathrm{ppm}$.

\section{Conclusions}

In this experiment, fertilizers had significant effect on the growth and yield of cabbage. The highest plant height, spread, leaf length, leaf breadth, head thickness, head diameter, period to head formation and maturity and marketable yield were obtained from the plot receiving $\mathrm{N}, \mathrm{P}$, $\mathrm{K}$ and $\mathrm{B}$ at the rates of $150,50,100$ and $3 \mathrm{~kg} / \mathrm{ha}$, respectively. The treatment $\mathrm{N}, \mathrm{P}, \mathrm{K}$ and $\mathrm{S}$ showed the highest weight of loose leaves. Single dose of boron was used in the present investigation. The study may be continued further to find out the yield potentiality of cabbage under different doses of boron.

\section{References}

Alam, M. N. 2007. The effect of different levels of Boron as boric acid on growth and yield of cabbage in calcareous soils of Bangladesh. Ph. D. Thesis, Dept. of Environmental Science, Rajshahi University, Rajshahi.

BARC. 2005. Fertilizer Recommendation Guide. Peoples Press \& Publications, Purana Paltan, Dhaka, Bangladesh. 260 pp.

BBS, 2009. Year Book of Agril. Statistics of Bangladesh. Bangladesh Bureau of Statistics, Ministry or Planning Govt. of the Peoples Republic of' Bangladesh, Dhaka.

Das, D. K. 1999. Introductory Soil Science. Kalyani publications. 1/1, Rajinder Nagar, Ludhiana-141008, India. 258-259 pp.

FAO. 2009. Food and Agriculture Organization of United Nations. Economical and Social Department. The Statistical Division, Rome, Italy.

Farid, A. T. M., Rahman, M., Talukder, K. H., Shahidullah, M. and Islam M.S. 1998. Efficiency of poultry manure and cowdung alone and in combination with mineral fertilizers on the yield of cabbage. Bangladesh Journal of Agricultural Research, 23(1): 157-165.

Gomez, K. A. and Gomez. A. A. 1984. Statistical Procedure for Agricultural Research (2nd Edn.). In: Rice Res. Inst. A Willey Int. Science Publication, 28-192 pp.

Haro, T. and Sonoda, Y. 1981. The role of micronutrient in cabbage head formation. Soil Science and Plant Nutrition, 27(1): 45-54.

Islam, M. S. 2002. Soil Fertility history, present status and future scenario in Bangladesh. A lecture presented in a training course on "Integrated Soil Fertility Management" held at CERDI on September 2002.

Islam, A. F. M. S., Forooque, A. M., Islam M. N. and Nasiruddin. K. M. 1989. Effect of age of seedlings and spacing on the performance of cabbage. Bangladesh Horticulture, 17(2): 25-29.

Jahiruddin, M. and Rijpma, J. 2004. Strategy and plan for use of soil nutrient balance in Bangladesh. Final report of short time assignment. SFFP/DANIDA.

Kamiyama, K. S., Fujiwara and Funahahsi, H. 1995. Effect of successive application of cow manure compost on growth crops and the chemical properties of the soil. Bulletin of Agricultural Research Institute of Kanagawa Prefecture. 136: 31-42.

Kanujia, S. P., N. Ahmed, M. A. Chattoo, N. Jabeen and S. Naryan. 2006. Effect of micronutrients on growth and yield of cabbage (Brassica oleracea var. capitata L.). Applied Biological Research, 8: 1518.

Sarma, P., Goswami, R. K. and Deka, B. C. 2002. Effect of foliar application of micronutrients on yield and quality of cabbage. Journal Plant Nutria, 25(8): 1701-1707. 
Tandon, H. L. S. 1995. Sulphur Research and Agricultural Production in India, 3rd edn. TSI, Washington DC. USA. 140 p.

Tisdale, S. L., Nelson, W. L., Beaton, J. D. and Havlin, J. L. 1995. Soil Fertility and Fertilizers (5th Ed.). Printice Hall of India Private Ltd., 301-342 pp.

Ullah, M.H., Chowdhury, M. M. U., Nabi, S. M., Sultana S. and Haider, N. K. 1999. A study on yield potentiality of cabbage as influenced by $\mathrm{N}, \mathrm{P}, \mathrm{K}$. and $\mathrm{S}$ fertilization.
Bangladesh Journal of Agricultural Research, 24(4): 637-643.

Uddin, M. J., Islam, M. M. and Naher, M. N. A. 2009. Basic Agriculture, Part I. 74/4, Upashahar, Rajshahi. 379 p.

Wang-Xiude, D., Wang, F. T., Liao, Z. X., Yung J. and Mao. P.1996. Study on formula selection and rational application amount of organic, inorganic granular fertilizer for some vegetable species. Acta Agriculture Shanghai, 12 (1):61-65. 